УДК $378 ; 371.134 ; 373.5 .016$

DOI:

Оксана Товканець, доктор педагогічних наук, доиент, професор кафедри загальної педагогіки та педагогіки вищої школи, ДВНЗ “Ужгородський національний університет”

\title{
УПРАВЛІНСЬКІ КОМПЕТЕНЦІЇ У ПРОФЕСІЙНІЙ ДІЯЛЬНОСТІ МЕНЕДЖЕРІВ З ОСВІТИ ДОРОСЛИХ В ЄВРОПЕЙСЬКОМУ ОСВІТНЬОМУ ПРОСТОРІ
}

У статті обтрунтовано роль управлінських компетенцій у професійній підготовці менеджерів з освіти дорослих в європейському освітньому просторі. Акцентовано увагу на тому, щуо в європейському просторі актуальною є освіта, яка забезпечує можливості успішного кар 'єрного і професійного зростання дорослих. Визначено дві групи компетенцій, які є важливими для менеджера в освіті дорослих: компетенції контролю та компетениії управління операчіями. Конкретизовано функиіональні обов'язки менеджерів у сфері освіти дорослих: планування національної політики в галузі освіти дорослих; розроблення відповідного нормативноправового забезпечення, підтримка внутрішньополітичних зв'язків, маркетинг та реклама закладу $і$ його діяльності; спілкування з роботодавцями та потенційними клієнтами курсів, пропонованих організацією mouso.

Ключові слова: управлінські компетенції; європейський освітній простір; менеджер з освіти дорослих; рівні управління системою освіти дорослих.

Puc. 1. Jim. 15.

Oksana Tovkanets, Doctor of Sciences (Pedagogy), Associate Professor, Professor of the General Pedagogy and Higher School Pedagogy Department,

SHEE "Uzhhorod National University"

\section{MANAGEMENT COMPETENCIES IN THE PROFESSIONAL ACTIVITIES OF ADULT EDUCATION MANAGERS IN THE EUROPEAN EDUCATIONAL SPACE}

The article substantiates the role of managerial competencies in the professional activity of adult education managers in the European educational space. An attention is focused on the fact that education is relevant in the European space, which provides opportunities for successful career and professional growth of adults. Two groups of competencies that are important for a manager in adult education are identified: control competencies and operations management competencies. It is emphasized that the tasks of the adult education manager are divided into four levels: national (creation of modern strategies and concepts that guarantee the effective functioning of the adult education system; development of modern legislation to facilitate the implementation of global and European priorities); regional (ensuring equal access to educational services for all adults, researching the educational needs of adults in accordance with the identified priorities, ensuring flexibility and accessibility of the adult education system); institutional (study of the educational needs of adults in order to form proposals for modern courses, educational programs, which allows you to maintain a high level of competitiveness of your own institution); the level of the educational process (providing flexible curricula; improving the quality of teaching materials, tools and means of conducting classes; purposeful search for feedback on the effectiveness of training). The functional responsibilities of managers in the field of adult education are specified: planning of national policy in the field of adult education; development of appropriate regulatory and legal support, support of internal political relations, marketing and advertising of the institution and its activities; communication with employers and potential clients of courses offered by the organization, etc.

Keywords: managerial competencies; European educational space; adult education manager; levels of management of the adult education system.

П остановка проблеми. Прискорення соціально-культурних змін як на глобальному, так і на локальному рівнях, швидкоплинність й ускладнення процесів сучасного життя за загальної тенденції його збільшення, суттєво підвищує роль освіти дорослих у розвитку сучасного суспільства. Як підкреслено у Національній доповіді про стан і перспективи розвитку освіти в Україні, їі соціальне значення посилюється сучасною демографічною ситуацією, характерною для європейських країн; складним соціально-політичним середовищем, де повноцінний розвиток особистості стає неможливим без активної участі в мінливих суспільних процесах й адаптації в умовах зростаючої мобільності до культурної, етнічної та мовної різноманітності [5].

Окрім того, новий тип економічного розвитку, притаманний сучасному інформаційному суспільству, спонукає неодноразово впродовж 


\section{УПРАВЛІНСЬКІ КОМПЕТЕНЦІЇ У ПРОФЕСІЙНІЙ ДІЯЛЬНОСТІ МЕНЕДЖЕРІВ З ОСВІТИ ДОРОСЛИХ В ЄВРОПЕЙСЬКОМУ ОСВІТНЬОМУ ПРОСТОРІ}

життя, змінювати соціальний і професійний статус, постійно підвищувати кваліфікацію. Отже, нині освіта перетинається 3 економічною й іншими сферами суспільства, а освітня діяльність стає надзвичайно важливою компонентою його розвитку. “Це означає, що інформація, знання, а також мотивація щодо їх постійного оновлення й навички, необхідні для цього, стають вирішальним чинником цивілізаційного розвитку, ефективності і конкурентоспроможності будь-якої діяльності, а відтак чинником суверенітету та національної безпеки кожної країни" [2, 4-5].

Аналіз останніх досліджень та публікацій. Проблема удосконалення управлінських компетенцій розглядалася вітчизняними і зарубіжними дослідниками, зокрема Л. Лук'яновою [2; 3], Г. Сухобською, Т. Шадріною [8] та чеськими науковцями Я. Ветешкою [14], 3. Паланом [12], В. Трояном, Т. Туречковою [14], болгарською вченою В. Гюровою [1] та іншими.

Значну увагу цій проблемі приділено в документах європейського і міжнародного рівня. У доповіді ЮНЕСКО йдеться про те, що неперервна освіта має вийти за рамки, притаманні розвиненим країнам, а саме: підвищення кваліфікації, перепідготовка або просування дорослих по службі. Натомість вона має відкрити можливості для всіх, зокрема надання другого або третього шансу в житті, задоволення прагнення до знань і краси або вдосконалення і розширення підготовки, безпосередньо пов'язаної з вимогами професійної діяльності, включаючи практичну підготовку [6]. В інших європейських документах також знаходимо підтвердження ролі освіти дорослих у розвитку держави, зокрема у розв'язанні проблем міграції, транснаціоналізації, гармонізації взаємин між поколіннями тощо. Надзвичайно важливим $є$ уміння дорослих прогнозувати, передбачати та проектувати зміни, які на початку XXI ст. стають індикаторами високого фахового й професійного рівня фахівця у професійній діяльності [10].

Отже, для успішного кар'єрного і професійного зростання дорослі люди повинні безперервно розвивати свої уміння та навички, удосконалювати знання, здобувати нові компетентності та отримувати нові кваліфікації як у формальному навчанні, так і у неформальному, що суттєво актуалізує процес професійної підготовки фахівців 3 менеджменту освіти у сфері освіти дорослих.

3'ясування особливостей підготовки фахівців 3 менеджменту освіти дорослих у центральноєвропейських країнах вимагає чіткого визначення сфери управління освітою дорослих, їх компетенцій тафункціональнихобов'язків таких фахівців.
Вивчення праць зарубіжних дослідників 3 означеної проблеми $[12 ; 14]$ засвідчує, що їх найбільшу увагу привертають такі напрями розвитку теорії управління освітою дорослих: міжнародний та національний рівні управління освітою дорослих; управління системами освіти дорослих у різних країнах; теорії управління, управління освітою та менеджменту освіта дорослих та їх прогнози та застосування в галузі освіти дорослих як практика; управління установами, що надають послуги 3 навчання дорослих студентів; підготовка та організація курсів 3 дорослими учнями; управління навчальним процесом 3 дорослими учнями; підготовка управлінського персоналу для галузі (та системи) освіти дорослих.

Мета статті: обгрунтувати роль управлінських компетенцій у професійній діяльності менеджерів 3 освіти дорослих в європейському освітньому просторі.

Виклад основного матеріалу. На думку провідних фахівців 3 менеджменту і освіти дорослих у центральноєвропейських країнах Я. Ветешки [14], В. Гюрової [1], обов’язки фахівців цієї сфери мають певні особливості. Загалом вчені виокремлюють дві групи компетенцій: контролю та управління операціями. По-перше, це контроль за виконанням завдань на національному або інституційному рівнях; по-друге, це управління операціями щодо виконання завдань як частина загального освітнього менеджменту.

Прокоментуємо їх більш грунтовно. Здійснення контролю за виконанням завдань на національному або інституційному рівнях полягає у спрямуванні працівників на результат, ефективність забезпечення контролюючих функцій, позитивне вирішення конфліктних ситуацій, створення системи лідерства. Окрім того акцентується увага на уміннях моделювання і розробки планів та стратегій, встановлення цілей та завдань щодо прийняття рішень та їх виконання, сприяння управліннями структур для виконання поставлених завдань, оцінки результатів (планування та проєктування, організація та контролю системи оцінювання в системі освіти); уміння здійснювати керівництво відповідним підрозділом на певному рівні управління (від організації в цілому до організації та виконання окремих завдань);

Натомість управління операціями з виконання завдань, як частина управління, спрямовано на розробку, програмування, контроль, прийняття управлінських рішень, застосування відповідних систем та методів, які забезпечуватимуть якість.

Схарактеризуємо більш детально досвід 


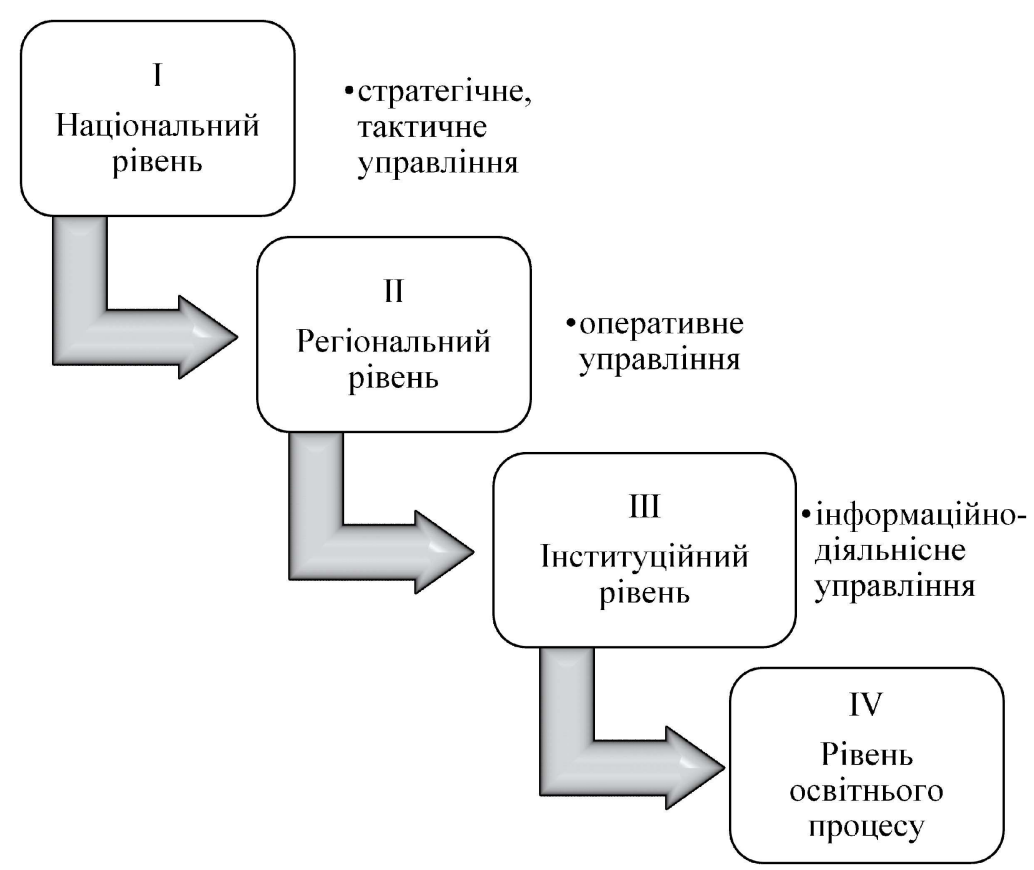

Рис. 1. Рівні управління системою освіти дорослих

діяльності фахівців з менеджменту і управління освіти дорослих у деяких країнах Центральної Свропи, зокрема, Словенії, Словаччині, Чехії, Болгарії.

У Болгарії в системі освіти дорослих, як і в будь-якій іншій галузі, є різні рівні управління (менеджмент) та різні менеджери, які забезпечують виконання цих функцій, відповідно.

Наприклад, на національному рівні - менеджер системи освіти дорослих; на рівні закладів, які пропонують послуги з навчання дорослих, $\epsilon$ кілька рівнів: старший керівник (та його команда); "середній” менеджер - менеджер підрозділу (наприклад, викладач в університеті) або кафедри в установі (наприклад, менеджер 3 персоналу), "нижчий” менеджер (наприклад, організатор курсу); на рівні управління навчальним процесом - виступає у ролі менеджера викладач або керівник групи тренерів.

На кожному рівні враховуються різні вимоги до посад, ролей та функцій освітніх менеджерів, зокрема на національному рівні - повноцінне функціонування системи освіти дорослих; на інституційному рівні - виживання та стійкість (конкурентоспроможність) інститут ринку освітніх послуг та підтримка його позитивного іміджу; на рівні управління навчальним процесом “ забезпечення всіх умов для успіху виконання поставлених цілей і завдань конкретного курсу; якості та ефективного навчання дорослих учнів.

Аналіз документальних джерел $[4 ; 13 ; 15$ та ін.] показав, що завдання щодо діяльності керівників з управління в освіті дорослих розподілені за чотирма рівнями (Рис.1).

1. Національний рівень. На цьому рівні здійснюється стратегічне, тактичне управління системою освіти дорослих, яке включає три основні напрями: створення сучасних стратегій та концепцій, які гарантують ефективне функціонування системи освіти для дорослих; розроблення сучасного законодавства для полегшення імплементації світових та європейських пріоритетів (стратегії і тенденції) для навчання впродовж життя; творення політики навчання дорослих та фінансування діяльності 3 навчання дорослих студентів. У сферу діяльності менеджерів підпадає і розвиток системи валідації знань, набутих поза межами формальної системи освіти.

2. Регіональний рівень. Діяльність менеджерів на цьому рівні полягає у забезпеченні рівного доступу до освітніх послуг для всіх дорослих, зокрема маргінальних груп i окремих маргіналізованих осіб, забезпечення обізнаності громадськості щодо освітніх заходів та освітніх проектів для різних категорій дорослих учнів (цільові групи). Окремий вид діяльності становлять дослідження освітніх потреб дорослих відповідно до визначених пріоритетів та тенденцій, а також вивчення потреб на ринку праці з метою організації та надання допомоги освітніх послуг 3 навчання дорослих; забезпечення гнучкості та доступності системи освіти для дорослих; використання потенціалу міжнародних програм 


\section{УПРАВЛІНСЬКІ КОМПЕТЕНЦЇ У ПРОФЕСІЙНІЙ ДІЯЛЬНОСТІ МЕНЕДЖЕРІВ}

ЗОСВІТИ ДОРОСЛИХ В ЄВРОПЕЙСЬКОМУ ОСВІТНЬОМУ ПРОСТОРІ

для вдосконалення системи та кваліфікацій фахівців у галузі освіти дорослих.

3. Інституційний рівень (закладів, щчо надають послуги з навчання дорослих). На цьому рівні відбувається стратегічне, тактичне та оперативне управління закладом. Менеджери, які працюють на цьому рівні, вивчають освітні потреби дорослих з метою формування пропозицій сучасних курсів, освітніх програм, що дає змогу підтримувати високий рівень конкурентоспроможності власної установи. До їх юрисдикції підпадають питання щодо забезпечення ділових контактів із зовнішнім середовищем установи, зокрема роботодавцями, ЗМІ тощо. Важливий напрям діяльності становить забезпечення персоналу для підготовки, організації та впровадження якості послуги з навчання дорослих; забезпечення (i відбір) кращих педагогів для закладу; залучення партнерів та спонсорів; підтримка хорошої та сучасної матеріально-технічної бази та ергономічності умови для навчання; забезпечення доброї та фінансово надійної реклами для установи та окремої людини. Використання міжнародних програм та проектів для фінансової підтримки освітньої діяльності та кваліфікації викладачів й організаторів; цілеспрямований пошук зворотного зв'язку щодо ефективності пропонованих курсів.

4. Рівень навчального процесу. На цьому рівні діяльність менеджерів зосереджена на забезпеченні ефективності процесу навчання. Передусім йдеться про контроль за постійним підвищенням кваліфікації викладачів; забезпечення гнучких навчальних програм; підвищення якості навчальних матеріалів, інструментів та засобів для проведення заняття; цілеспрямований пошук відгуків щодо ефективності навчання.

Оскільки менеджери освіти дорослих $\epsilon$ передусім андрагогами, отже вони, як і увесь педагогічний персонал освіти дорослих виконують багато функцій. 3 цього приводу Л. Лук'янова підкреслює, що андрагогів та їх соціальну роль у суспільстві не можна брати до уваги тільки 3 позиції реальної потреби життя, оскільки мова йде про виконання специфічних функцій або ролей, а не просто професійно підготовлених фахівців, які володіють відповідними компетенція [3, 16-18]. На думку Г. Сухобської, та Т. Шадріної, “андрагог” це не професія, як і “"педагог”. Це узагальнена назва різних інформаційно-освітніх ролей. Якщо центральну позицію посідає процес навчання, тоді це “вчитель”, “викладач”, якщо мова йде про формування духовно-моральної сфери особистості, а також форми людської поведінки, це-вихователь, якщо консультування для самонавчання “тьютор”, “консультант” тощо [8].
Конкретизація функціональних обов'язків менеджерів у сфері освіти дорослих на національному та регіональному рівнях дає підставу включити до кола цих обов'язків планування національної політики в галузі освіти дорослих; розроблення відповідного нормативно-правового забезпечення, стратегій і програм щодо організації та управління системою й установами освіти дорослих; організація заходів щодо з популяризації освіти дорослих (наприклад, “Дні / тиждень освіти дорослих", національні форуми для зустрічі з роботодавцями та представниками сфери освіти дорослих; підтримка внутрішньополітичних зв'язків 3 представниками уряду у різних комітетах та підкомітетах і міжнародних зв'язків з галузевої політики освіти дорослих; координація проєктів загальнодержавного масштабу щодо освіти дорослих, що фінансуються міжнародними та національними програмами; контроль виконання національно важливих планів та стратегій, що стосуються освіти дорослих взагалі та її окремих аспектів зокрема.

На рівні навчального закладу / навчального процесу вчитель (або тренери) курсу - фахівець 3 менеджменту освіти здійснює діяльність пов'язану із діагностикою рівня попередніх знань і умінь (визначає залишкові знання); планує зміст освіти відповідно до потреб цільової групи, мети та завдань, тривалості та інтенсивності курсу з урахуванням можливостей матеріально-технічної бази (включаючи навчальні матеріали та посібники). Слід звернути увагу і на таку діяльність, як безпосереднє структурування навчальної програми за темами та конкретними заняттями; розроблення портфоліо курсу; підготовка матеріалів для учасників. Неабияку роль у цьому процесі відіграє контролююча функція, зокрема контроль навчальної роботи; контроль дотримання графіку діяльності, мікроклімату, участі слухачів 3 навчальної діяльності; і загалом, дотримання умов для здійснення ефективності навчального курсу. А також координуюча (координує виконання програми, планів занять, завдань для індивідуальної та групової роботи) та оцінювальна (оцінює ефективність кожної групи та курсу загалом).

Уважаємо за доцільне звернути окрему увагу на діяльність менеджерів, які працюють у підсистемі неформальної освіти дорослих. Сьогодні, як підкреслюють дослідники, система неформальної освіти у розвинених країнах посідає один щабель 3 формальною, а подекуди й вищий, оскільки саме тут людина знаходить оптимальні 


\section{УПРАВЛІНСЬКІ КОМПЕТЕНЦІЇ У ПРОФЕСІЙНІЙ ДІЯЛЬНОСТІ МЕНЕДЖЕРІВ ЗОСВІТИ ДОРОСЛИХ В ЄВРОПЕЙСЬКОМУ ОСВІТНЬОМУ ПРОСТОРІ}

умови для творчого особистісного розвитку [2; 7]. Наприклад, за даними Інституту ЮНЕСКО, у розвинених країнах світу кількість дорослих учасників освітніх програм набагато перевищує кількість дітей і підлітків, які навчаються. У цих же країнах різноманітною освітньою й просвітницькою діяльністю охоплено до 40-50 \% дорослого населення [11]. Такий підвищений інтерес до неформальної освіти, на думку І. Скринник сформувався за рахунок ії гнучкості, різноманітності форм, а також великих можливостей соціалізації особистості, в опановуванні нових соціальних ролей, сприянні духовному розвитку, самоосвіті й самовихованню $[7,20]$.

У закладах неформальної освіти дорослих у Словенії, Словаччині, Чехії загалом фахівець 3 менеджменту освіти (керівник або ж менеджери за окремими напрямами) забезпечує різні види діяльності. Передусім вони здійснюють опитування щодо освітніх потреб (групових та індивідуальних) знань (курсів), попиту та пропозиції навчальних курсів на ринку освітніх послуг дорослих, нових “незайнятих” сфер діяльності, тенденцій та потенційних клієнтів тощо. До їх інших посадових обов'язків також належить планування (курсів, які пропонуються протягом відповідного року; доходів та витрат); маркетина ma реклама закладу та його діяльності; спілкування 3 роботодавцями та потенційними клієнтами курсів, пропонованих організацією. Вони також керують персоналом, зокрема мотивують працівників до відповідальності за свою роботу, впровадження якісного навчального процесу, а також координують ділові відносини із зовнішніми партнерами, спонсорами тощо та здійснюють контроль усієї діяльності в організації (навчальна, матеріально-технічна, адміністративна).

Великий обсяг роботи виконують управлінці рівня індивідуального курсу. Як організатори курсу (або курсів - як посади) за змістом діяльності вони розробляють стратегію залучення клієнтів для конкретного курсу, готуються прес-релізи та інші рекламні матеріали; комунікують 3 роботодавцям та іншими потенційними учасниками. Саме на них покладається остаточний вибір заявників та формування групи. Найбільші навантаження пов'язані із організаційною діяльністю. Окрім того, що менеджер розробляє погодинно програму заходу (для семінару, лекції, робочої групи тощо), він, за потреби, організовує навчальну базу можливих курсів (якщо установа не має власної); планує доходи та витрати; забезпечує вибір тренерів попередньо вивчає можливості викладачів, опитуючи або відбираючи документи, надаючи відгуки, ранжує, узгоджує умови курсу та вимоги викладачів. До цих обов'язків слід додати і логістику - перевезення, організація розміщення й відправлення учасників та інше [9; 10].

На них покладається і функція оцінювання ефективності курсу. Загалом такий зворотній зв'язок може мати різні форми, зокрема, проведення анкетування, отримання відгуків про ефективність курсу слухачами, тренерами, роботодавцями (якщо такі є), експертами тощо.

Виконання всіх відповідальних завдань (мотивація дорослих і планування їх навчальної роботи, документальне забезпечення організації в освіті дорослих та інше) потребує від керівників різних рівнів управління у сфері освіти дорослих (та відповідних установ, що надають освітні послуги для дорослих) спеціальної підготовки та врахування національних і міжнародних тенденцій.

Одним із основних факторів успішності сучасного менеджера з освіти дорослих є високий рівень професійної компетентності, однією 3 важливих складових якої стає управлінська компетентність. Управлінську компетентність пропонується розуміти як інтегральну динамічну інтелектуально-особистісну характеристику, що відображає прагнення, готовність та здатність менеджера 3 освіти дорослих професійно вирішувати завдання організації та управління колективом, групою на підставі набутих організаційних та управлінських знань та умінь, а також ціннісних орієнтацій.

\section{ЛІТЕРАТУРА}

1. Гюрова, В. Лидерска роля и компетентност на ръководителя (мениджъра) на институция за образование на възрастни. Книга "Педагогика". Т. 102, Годишник на СУ “Св. Климент Охридски”, 2009. С. 60 66.

2. Лук'янова, Л. Б. Концепція розвитку освіти дорослих в Україні (2 ге вид.). 2016. Київ: ТОВ “ДКСЦентр".

3. Лук'янова, Л. Б. Професійні ролі педагогічного персоналу системи освіти дорослих. Сучасні інформаційні технології та інноваційні методики навчання у підготовці фахівців: методологія, теорія, досвід, проблеми, 2014. № 40. С. 16-2.

4. Национална стратегия за учене през целияживот (УЦЖ) за периода 2008-2013 URL: http://www.mon.bg/ opencms/export/sites/mon/left menu/documents/ strategies/LLL strategy 01-10-2008.pdf

5. Національна доповідь про стан і перспективи розвитку освіти в Україні. 2021, https://naps.gov.ua/ua/ press/releases/1001/

6. Образование: Сокрытое сокровище. Доклад Международной комиссии по образованию для XXI века, представленный ЮНЕСКО. Издательство ЮНЕСКО. 1996.31 c. 


\section{УПРАВЛІНСЬКІ КОМПЕТЕНЦІЇ У ПРОФЕСІЙНІЙ ДІЯЛЬНОСТІ МЕНЕДЖЕРІВ ЗОСВІТИ ДОРОСЛИХ В ЄВРОПЕЙСЬКОМУ ОСВІТНЬОМУ ПРОСТОРІ}

7. Скринник, И. К. Неформальное образование как средство повышения эффективности деятельности некоммерческих организаций: автореф. канд. пед. наук. Ставропольский государственный университет, Ставрополь 2006.

8. Сухобская, Г.С., Шадрина Т.В. Андрагогическая направленность профессионально-педагогического образования: социокультурные предпосылки. 2013. URL: http://ext.spb.ru/index.php/2011-03-29-09-03-14/108custom-person>

9. Товканець, О.С. Підготовка фахівців 3 менеджменту освіти в центральноєвропейських країнах: теорія і практика (друга половина XX - початок XXI ст.): монографія. За заг. ред. Л. Б. Лук'янової. Ужгород : ТОВ “РІК-У”. 2019.516 c.

10. European Society for Researchon the Education of Adults -ESREA. (nd). URL: http://www.esrea.org/?1=en

11. OECD. Education at a Glance 2011: OECD Indicators. Paris: OECD Publishing. 2011. URL:https:// doi.org/10.1787/19991487

12. Palán, Z. Výkladový slovník lidské zdroje. Praha: Academia. 2002.280 s.

13. UNESCO. CONFINTEA V: The Hamburg Declaration on Adult Learning.1997. URL:http:// www.unesco.org/education/uie/confintea/declaeng.htm;

14.Veteška, J. Tureckiová, M., Trojan, V. Aktální př́stupy managementu vzdělávání. 2017. Praha: Centrum školského managementu Pedagogické fakulty Univerzity Karlovy.

15. Zákon. Zákon o celoživotnom vzdelávaní a o zmene a doplnení niektorých zákonov. Národná rada Slovenskej republiky. 2009.(vznení č. 315/2012 Z. z., 315/2012 Z. z., 292/2014 Z. Z., 188/2015 Z.)

\section{REFERENCES}

1. Gyurova, V. (2009). Liderska rolya i kompetentnost na rykovoditelya (menidzhera) na institucziya za obrazovanie na vzrastni [Leadership role and competence of the head (manager) of an adult education institution]. Vol. 102, pp. 60 - 66. [in Bulgarian].

2. Lukianova, L. B. (2016). Kontseptsiia rozvytku osvity doroslykh $\mathrm{v}$ Ukraini [The concept of adult education development in Ukraine]. (2nd ed.). Kyiv. [in Ukrainian]

3. Lukianova, L. B. (2014). Profesiini roli pedahohichnoho personalu systemy osvity doroslykh [Professional roles of pedagogical staff of the adult education system]. Modern information technologies and innovative teaching methods in training: methodology, theory, experience, problems, no. 40, pp.16-2. [in Ukrainian].

4. Naczionalna strategiya za uchene prez czeliyazhivot (UCZh) za perioda 2008-2013 [National Strategy for
Lifelong Learning (LLL) for the period 2008-2013]. Available at: http://www.mon.bg/opencms/export/sites/ mon/left_menu/documents/strategies/LLL_strategy_0110-2008.pdf [in Bulgarian].

5. Natsionalna dopovid pro stan i perspektyvy rozvytku osvity v Ukraini 2021 [National report on the state and prospects of education in Ukraine]. Available at: https://naps.gov.ua/ua/press/releases/1001/

6. Obrazovanie: Sokrytoe sokrovishhe (1996). [Education: A Hidden Treasure]. Report of the International Commission on Education for the 21st Century, submitted to UNESCO. 31 p. [in Russian].

7. Skrinnik, I. K. (2006). Neformalnoe obrazovanie kak sredstvo povysheniya effektivnosti deyatelnosti nekommercheskikh organizaczij [Non-formal education as a means of increasing the efficiency of non-profit organizations]. Extended abstract of candidate's thesis. Stavropol State University, Stavropol. [in Russian].

8. Sukhobskaya, G.S. \& Shadrina, T.V. (2013). Andragogicheskaya napravlennost professionalnopedagogicheskogo obrazovaniya: socziokulturnye predposylki [Andragogical orientation of vocational pedagogical education: socio-cultural prerequisites]. Available at: http://ext.spb.ru/index.php/2011-03-29-09-0314/108-custom-person [in Russian].

9. Tovkanets, O.S. (2019). Pidhotovka fakhivtsiv z menedzhmentu osvity $\mathrm{v}$ tsentralnoievropeiskykh krainakh: teoriia i praktyka (druha polovyna XX - pochatok XXI stolittia) [Training of specialists in education management in Central European countries: theory and practice (second half of the XX - beginning of the XXI century)]. Monohraf. (Ed.). L. B. Lukianova. Uzhhorod, 516 p. [in Ukrainian].

10. European Society for Researchon the Education of Adults - ESREA. (nd). Available at: http://www.esrea.org/ ?l=en [in English].

11. OECD. (2011). Education at a Glance 2011: OECD Indicators. Paris: OECD Publishing. https://doi.org/ 10.1787/19991487[in English].

12. Palán, Z. (2002). Výkladový slovník lidské zdroje [Glossary of human resources]. Praha, 280 p. [in Czech].

13. UNESCO. (1997). CONFINTEA V: The Hamburg Declaration on Adult Learning. Available at: http:// www.unesco.org/education/uie/confintea/declaeng.htm [in English].

14. Veteška, J., Tureckiová, M., Trojan, V. (2017). Aktuální přístupy managementu vzdělávání [Current approaches to education management]. Praha. [in Czech].

15. Zákon (2009). Zákon o celoživotnom vzdelávaní a o zmene a doplnení niektorých zákonov [The law Act on Lifelong Learning and on Amendments to Certain Acts]. Národná rada Slovenskej republiky.(vznení č. 315/2012 Z.z., 315/2012 Z. z., 292/2014 Z. Z., 188/2015 Z.) [in Czech].

Стаття надійшла до редакції 09.11.2021

G5808NC2058080

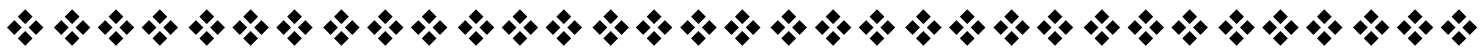

